\section{AZ UTOLSÓ FELKÉSZÜLÉSI CÉLÚ SZOLVENCIA II MENNYISÉGI HATÁSTANULMÁNY EREDMÉNYEI}

Bora Zsuzsanna (junior aktuárius), Holczinger Norbert (osztályvezetö), Merész Gabriella (aktuárius), Velcsov Gabriella (aktuárius), Zubor Zoltán (vezetó aktuárius)

Magyar Nemzeti Bank

\section{ÖSSZEFOGLALÓ}

Az MNB által lefolytatott, 2014. év végi adatokon alapuló hatástanulmány kiemelt jelentőséggel bír, mivel ez a Szolvencia II rendszer bevezetése előtti utolsó felkészülési célú gyakorlat. A Szolvencia II hatálya alá tartozó teljes biztosítási piacot lefedő menynyiségi hatástanulmány eredményei összhangban vannak a korábbi felmérésekkel, azaz a Szolvencia II bevezetéséből fakadó mennyiségi követelményeknek való megfelelés az intézmények többségének nem jelent gondot, néhány esetben azonban tőkebevonásra van szükség. Jelentős változás a 2014-es hatásfelméréshez képest, hogy a hozamgörbe lényegesen lejjebb tolódott, ami az államkötvények folytatódó felértékelődését, valamint a Szolvencia I és Szolvencia II szerint számolt biztosítástechnikai tartalékok eltérésének csökkenését okozta. A legutóbbi öt hatástanulmány eredményei azt mutatják, hogy az új rezsimben várhatóan megnő a tőkehelyzet volatilitása.

\section{SUMMARY}

The Quantitative Impact Study on 2014 year-end data (hereinafter: QIS2014) conducted by the Magyar Nemzeti Bank (the Central Bank of Hungary) has a particular importance as it was the last preparatory exercise before Solvency II entering into force. The QIS2014 covers the whole insurance market falling under the scope of Solvency II. The results of the current study are in accordance with the previous ones, as most of the insurance companies are expected not to have difficulties in fulfilling the quantitative requirements of Solvency II. As a consequence of the differences among the insurers, in some cases capital enhancing measures are needed. Since QIS2013 there has been a significant change in the level of the interest rate term structure shifting down which improved the value of government bonds and reduced the difference between the value of technical reserves under Solvency I and Solvency II. Based on the comparison of the last five QISs' results, the volatility of capital is expected to increase under the new regime.
Kulcsszavak: Szolvencia II, hatástanulmány, szavatoló tőke, tőkeszükséglet, tőkefeltöltöttség

Key words: Solvency II, Quantitative Impact Study, solvency capital, capital requirement, solvency ratio

\section{JEL: G22, G29, G32}

\section{DOI: $10.18530 / B K .2016 .1 .14$}

http://dx.doi.org/1018530/BK.2016.1.14

\section{Bevezetés $^{1}$}

A Magyar Nemzeti Bank (a továbbiakban: MNB) a 2016. január 1-jén bevezetésre kerülő Szolvencia II rendszer adatszolgáltatási követelményeire való felkészülés céljából 2014 januárjában felkérte a - várhatóan Szolvencia II hatálya alá tartozó - biztosítókat az EIOPA által kiadott iránymutatások (EIOPA, 2013) szerint meghatározott információk benyújtására. A gyakorlat célja az volt, hogy a biztosítók a felkészülési szakaszban megismerkedjenek a Szolvencia II rendszer hatálya alatt érvényes adatszolgáltatás tartalmával, és felkészüljenek az előállításukkal kapcsolatos intézkedésekre.

Az MNB 2015 tavaszán számos konzultációt tartott a piaci szereplők részére, melyek

\section{9 biztosító határidőre teljesítette a}

felkészuilési célú adatszolgáltatást.

során tartalmi és technikai jellegű kérdésekre adott válaszaival segítette a biztosítók felkészülését. Minden érintett, összesen 29 biztosító határidőre teljesítette a felkészülési célú adatszolgáltatást, melynek keretében az MNB-hez XBRL formátumban beérkeztek a 2014. évre vonatkozó számszerű információk, valamint a szűkített tartalmú szöveges jelentések. Ezt követően az MNB ellenőrizte a beküldött adatok minőségét, és a biztosítókkal együttműködve megtörtént a hibás adatok javítása. 2015. július 2-án a magyar biztosítási piac 80 százalékát lefedő biztosítók felkészülési célú adatszolgáltatása továbbításra került az EIOPA felé.

Az MNB a felkészülési célú adatszolgáltatás során beérkezett 2014. év végi adatokon Szolvencia II mennyiségi hatástanulmányt (a továbbiakban: QIS2014) folytatott le. A QIS2014 fö célja az volt, hogy felmérje a Szolvencia II bevezetésének hatását a biztosítók pénzügyi helyzetére nézve szektor-, illetve egyedi intézményi szinten, az új rezsim bevezetése előtt egy évvel. 
Az alábbiakban részletes tájékoztatást nyújtunk a hazai intézmények 2014. év végére vonatkozó Szolvencia II szerinti adatai alapján a szektorszintű folyamatokról és mennyiségi elemekről, így kiemelten a mérlegről, a szavatoló tőke, valamint a szavatolótőke-szükséglet összetételéről és alakulásáról.

\section{A Szolvencia II mennyiségi hatástanulmány eredményei 2014 végén}

A Szolvencia II rendszerben a gazdasági értékelést kell alkalmazni, amelynek értelmében a mérlegtételek értéke megegyezik a piaci árral, illetve ennek hiányában egy modellezett értékkel. Mind az eszközárak, mind az értékelési modellek esetében kiemelt fontosságú a hozamkörnyezet: egyrészt a hazai biztosítók mérlegében kitüntetett szerepe van a (magyar) állampapíroknak (2. ábra), másrészt a diszkontálás révén a kötelezettségoldal értékelésében is kulcsszerepet játszik a hozamgörbe. Az EIOPA által meghatározott kockázatmentes hozamgörbe (EP, 2009, 77e. cikk) a 2013. év végére vonatkozó hatástanulmány óta (a továbbiakban: QIS2013) jelentősen lejjebb tolódott (1. ábra), aminek hatása a mérleg mindkét oldalán megjelent.

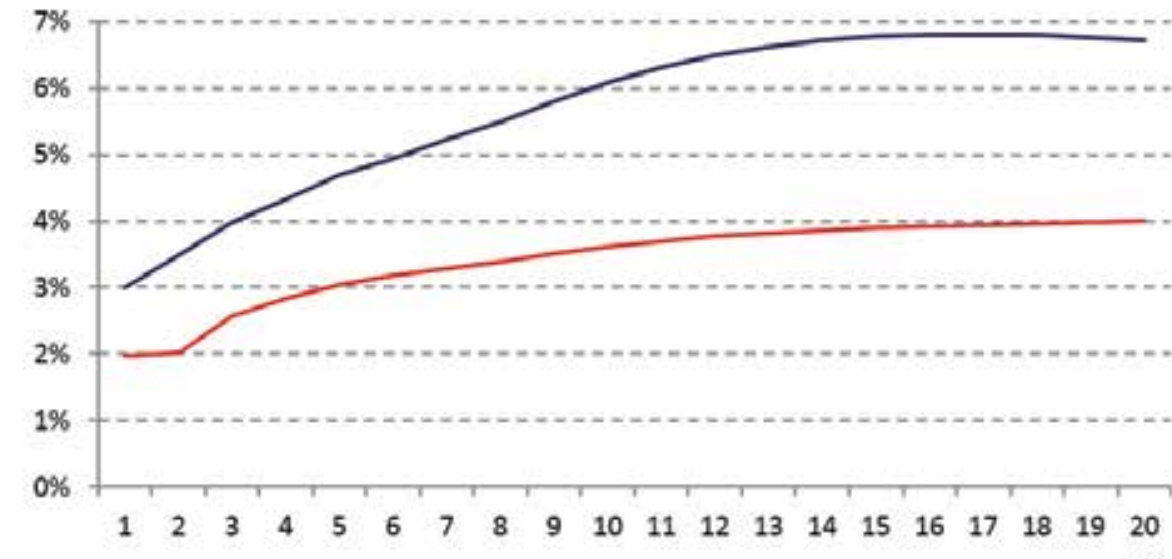

1. ábra: A forint kockázatmentes hozamgörbe 2013. és 2014. év végén.

1.1 A Szolvencia II gazdasági értékelés hatása az eszközökre és a biztosítástechnikai tartalékokon kívüli egyéb kötelezettségekre

A gazdasági értékelés a hazai számviteli rendszertől jelentősen különbözik, amit jól mutat az eszközök és kötelezettségek Szolvencia I és Szolvencia II értékének eltérése ${ }^{1}$.

\subsubsection{Eszközök}

A Szolvencia II szerinti eszközérték összességében 1 százalékkal magasabb a
Szolvencia I értékhez képest, és 2014 végén meghaladta a 2630 milliárd forintot. Ez

\section{A Szolvencia II szerinti eszközérték összességében 1 \\ százalékkal magasabb a Szolvencia I értékhez képest.}

a különbség annak ellenére alakult ki, hogy - az eltérő értékelési alapelvek miatt az immateriális javak, halasztott szerzési költségek, halasztott adókövetelések és a viszontbiztosítóval szembeni követelések összességében 109 milliárd forinttal kisebb értékkel szerepelnek a Szolvencia II-es eszközök között.

Immateriális javak és goodwill

Üzleti értéket (goodwill) nem mutatott ki egy biztosító sem, míg az immateriális javak értékét három biztosító vette figyelembe a Szolvencia II eszközértékei között. Mivel a többi biztosító ezen eszközöket 0 Ft értékben mutatta ki a Szolvencia II-es mérlegben, így általánosságban elmondható, hogy a szavatoló tőke szempontjából óvatos értékelést folytattak az intézmények.

\section{Halasztott szerzési költségek}

A Szolvencia II eszközérték csökkenéséhez hozzájárul, hogy a Szolvencia II értékelés során a halasztott szerzési költségek értéke 0 forint, míg a Szolvencia I-ben a halasztott szerzési költségek értéke a teljes eszközérték 1,6 százalékát jelenti, 40414 millió forinttal. Tekintettel azonban arra, hogy hatása már máshol (pénzáramlás-alapú tartalékmodellekben) figyelembevételre kerül, a duplázódás elkerülése érdekében a halasztott szerzési költségek a Szolvencia II értékeléskor 0 forint értéken szerepelnek az eszközök között.

\section{Halasztott adókövetelések}

A biztosítóknál jellemzően a céltartalék képzése, illetve a biztosításközvetítőkkel szembeni kintlévőségekre elszámolt értékvesztés miatt keletkezik halasztott adókövetelés, mivel azokat a hazai adójogszabály nem ismeri el adóalapot csökkentő tételként, ellenben a Szolvencia II feltételezi a tényleges gazdasági érték kimutatását. A teljes halasztott adókövetelés 91 százaléka három biztosítónál jelentkezik.

\section{Viszontbiztosítóval szembeni követelés}

A Szolvencia II értékelés szerint a viszontbiztosítóval szembeni követelések nagysága kevesebb mint felére csökkent, elsősorban a nem-életbiztosítási ághoz kötődő viszontbiztosítás átértékelődése miatt. Az eltéréshez ugyanakkor a viszontbiztosítás szempontjából kevésbé releváns életbiztosítási ág is hozzájárult, a két intézménynél megjelenő, hagyományos életbiztosítási termékekhez köthető negatív viszontbiztosítási követelések révén. 
Milliárd Eszközök
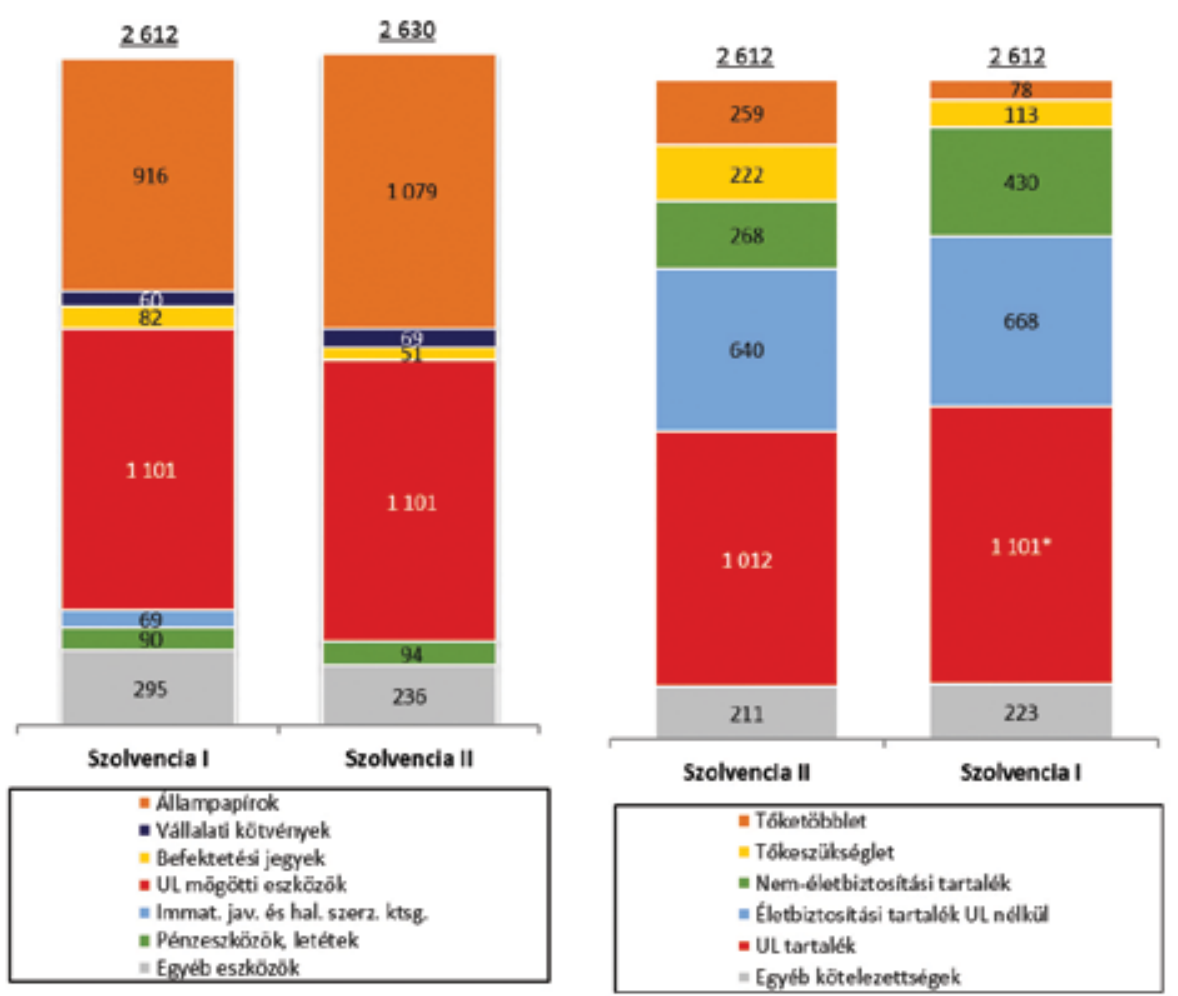

2. ábra: Mérleg átértékelődése Szolvencia I és Szolvencia II szerint

\section{A legnagyobb értékküilönbözet a közvetlenüil az állam \\ által garantált értékpapírok esetében merült fel.}

\section{Befektetések}

A legnagyobb értékkülönbözet a közvetlenül az állam által garantált értékpapírok esetében merült fel: a Szolvencia II eszközérték 18 százalékkal magasabb a Szolvencia I szerinti, piaci szinten összesített eszközértéknél. Ez egyértelműen az állampapír-piaci hozamkörnyezet 2013 tavaszától elinduló jelentős csökkenésére vezethető vissza. A 2014-ben is folytatódó kamatcsökkentések hatását jól mutatja, hogy míg a QIS2013-ban is részt vett 23 biztositó által birtokolt állampapírok Szolvencia I szerinti értéke gyakorlatilag nem változott 2013 év vége óta, a Szolvencia II szerinti érték 65 milliárd forinttal emelkedett. Az életbiztosítók esetében magasabb arányú értékelési különbözet tapasztalható, mivel e biztositók jellemzően hosszú távú ('́gy kamatérzékenyebb) állampapír-befektetéseket tartanak.

\begin{tabular}{|l|c|c|c|}
\hline & \multicolumn{2}{c}{$\begin{array}{c}\text { Szolvencia I } \\
\text { 2014 }\end{array}$} & \multicolumn{2}{c}{ QIS2014 } & $\begin{array}{c}\text { QIS2014/ } \\
\text { Szolvencia I } \\
\text { Immateriális javak* }\end{array}$ & 29052 & 321 & $1 \%$ \\
\hline Halasztott szerzési költségek & 40414 & 0 & $0 \%$ \\
Halasztott adókövetelések & 0 & 17111 & - \\
Befektetések & 1146798 & 1270047 & $111 \%$ \\
$\quad$ Állam által garantált értékpapírok & 915604 & 1078680 & $118 \%$ \\
$\quad$ Vállalati kötvények & 59598 & 68856 & $116 \%$ \\
$\quad$ Befektetési jegyek & 81735 & 50784 & $62 \%$ \\
$\quad$ Egyéb befektetések & 89861 & 71727 & $80 \%$ \\
Unit-linked eszközök & 1100665 & 1101301 & $100 \%$ \\
Viszontbiztosítóval szembeni követelések & 103845 & 46954 & $45 \%$ \\
Egyéb eszközök & 191240 & 194370 & $102 \%$ \\
\hline Eszközök összesen & $\mathbf{2 6 1 2 0 1 4}$ & $\mathbf{2 6 3 0 1 0 4}$ & $\mathbf{9 9 \%}$
\end{tabular}

1.táblázat: A átértékelési hatás bemutatása az eszközök esetében

A befektetések közé tartozó befektetési jegyek értékkülönbségét alapvetően az áttekintés (ún. „look-through”) elvének alkalmazása magyarázza, melynek értelmében a befektetési jegyek mögötti eszközöket a megfelelő soron mutatja ki a biztosító. Ezt mutatja a fent részletezett, például a kötvényeknél és részvényeknél tapasztalt ellentétes irányú értékkülönbség.

\subsubsection{Kötelezettségek}

A Szolvencia II szerinti összes kötelezettség értéke 10 százalékkal alacsonyabb a Szolvencia I-es értékhez képest, amely 2014 végén meghaladta a 2131 milliárd forintot. Az összes kötelezettség értékét a biztosítástechnikai tartalékok alakulása mozgatja, melyek részletes elemzése a 2.2. fejezetben olvasható.

A tartalékon kívüli kötelezettségek közül az alábbiak értéke változott a legnagyobb mértékben:

\begin{tabular}{|c|c|c|c|}
\hline & $\begin{array}{c}\text { Szolvencia I } \\
2014\end{array}$ & QIS2014 & $\begin{array}{c}\text { QIS2014/ } \\
\text { Szolvencia I } \\
2014\end{array}$ \\
\hline Biztositástechnikai tartalékok & 2210430 & 1920390 & $87 \%$ \\
\hline Halasztott adó kötelezettség & 0 & 63026 & - \\
\hline Egyéb kötelezettségek & 210911 & 147708 & $70 \%$ \\
\hline Összes kötelezettség & 2421341 & 2131122 & $90 \%$ \\
\hline
\end{tabular}

2. táblázat: Kötelezettségek bemutatása Szolvencia I és Szolvencia II szerint 


\section{Halasztott adó kötelezettség}

A halasztott adó kötelezettség a számviteli elméleti adófizetési kötelezettséget mutatja be, amely az adómérleg szerinti (gyakorlatilag Szolvencia I-es) értéke és piaci értéke közötti különbségből számítható összeg. A halasztott adó kötelezettség tételei lehetnek például tárgyi eszközökhöz kapcsolódó különbség, amortizált bekerülési érték elszámolása. Mivel a hazai számviteli törvény szerint a halasztott adó bemutatása nem megengedett, a Szolvencia II-es érték kimutatása a Szolvencia II-es kötelezettségek értékének növekedését okozza (63026 millió forint, amely a Szolvencia II összes kötelezettség 3\%-a).

\section{Egyéb kötelezettségek}

Az egyéb (nem biztosítási) kötelezettségek értékelésekor a biztosítók jellemzően a Szolvencia I szerinti vagy ahhoz nagyon közeli értéket tüntettek fel Szolvencia II értékként. A mintegy 64 milliárd forintnyi átértékelési különbözet nagyrészt a Szolvencia II rezsimben megszünő nagy károk tartalékához és a káringadozási tartalékhoz köthető.

\section{A Szolvencia I és II tartalékok kisebb eltéréséért \\ a hozamgörbe lejjebb tolódása a felelös.}

\subsection{Biztosítástechnikai tartalékok}

A 2014 végi Szolvencia II-es biztosítástechnikai tartalékok értéke 13 százalékkal marad el a Szolvencia I szerinti értéktől. A különbség 4 százalékponttal alacsonyabb, mint a QIS2013 során tapasztalt érték. A Szolvencia I és II tartalékok kisebb eltéréséért a tipikus okok ${ }^{2}$ közül döntően a hozamgörbe lejjebb tolódása a felelös ${ }^{3}$.

A hagyományos életbiztosítások tartalékánál becslésünk szerint a kockázatmentes hozamgörbe átlagosan 4179 bázispontos csökkenése a 2014. év végi tartalék nagyságát - ceteris paribus - közel 14 százalékkal növelte 2013 végéhez képest. A nem-életbiztosítási tartalékoknál hasonló megállapítást tehetünk.

\begin{tabular}{|c|c|c|c|}
\hline & Szolvencia I 2014 & QIS2014 & $\begin{array}{c}\text { QIS2014/ } \\
\text { Szolvencia I } 2014\end{array}$ \\
\hline $\begin{array}{l}\text { Életbiztositási tartalékok (nem- } \\
\text { élet járadéktartalék és UL nélkül) }\end{array}$ & 667669 & 639510 & $96 \%$ \\
\hline Unit-linked tartalék & $1112523^{*}$ & 1012490 & $91 \%$ \\
\hline $\begin{array}{l}\text { Nem-életbiztosítási tartalék } \\
\text { (nem-élet járadéktartalékkal)** }\end{array}$ & 430239 & 268389 & $62 \%$ \\
\hline Összesen & 2210430 & 1920390 & $87 \%$ \\
\hline
\end{tabular}

3. táblázat: A Szolvencia II hatása a biztositástechnikai tartalékok értékére

\subsection{1 Életbiztosítási tartalékok}

Az életbiztosítási tartalékok Szolvencia II szerinti értéke 93 százalékát teszi ki a Szolvencia I szerinti összegnek. A hagyományos termékek esetében az átértékelésből adódó csökkenés mértéke 4 százalék, a unit-linked portfóliónál 9 százalékos visszaesés figyelhető meg. A tartalékok mérséklődésének oka a diszkontálás, valamint a nyereséges termékek negatív Szolvencia II-es tartaléka. Ugyanakkor a hagyományos termékek Szolvencia II szerint kalkulált tartalékainak csökkenésében a diszkontálás hatása egyre kevésbé játszik szerepet, mivel az alacsony hozamkörnyezet következtében a jelenérték-számításhoz használt hozamráta már sok esetben alatta marad a technikai kamatlábnak. A unit-linked tartalékok esetén az átértékelés hatása - ellentétben a korábbi hatástanulmányok eredményeivel (MNB, 2015; PSZÁF, 2012) - magasabb, mint a nem unit-linked életbiztosítási kötelezettségek esetében.

A hagyományos életbiztosítási termékekre kalkulált legjobb becslés értéke 2014. év végén 623764 millió forintot, míg ugyanez a unit-linked termékek esetében 898589 millió forintot tett ki. A résztvevő biztosítók közül két intézmény a unit-linked tartalék egy részét replikáló portfólió segítségével (ún. „as a whole” módszerrel) kalkulálta, a másik részét legjobb becslés és kockázati ráhagyás összegeként. A legjobb becslés mindkét biztosító esetében a nyereséges részportfólió miatt negatív unit-linked tartalékot eredményezett.

Kockázati ráhagyás

A biztosítók többsége egyszerüsített módszerrel, jellemzően a szavatolótőke-szükséglettel vagy a legjobb becsléssel arányosan határozta meg a kockázati ráhagyás nagyságát. A hatástanulmányban egy biztosító jelezte, hogy duration-alapú számítást alkalmazott. A kockázati ráhagyás a legjobb becslés 2,2 százalékát tette ki 2014 végén.

\begin{tabular}{|c|c|c|c|}
\hline & Teljes életbiztositási tartalék & $\begin{array}{c}\text { Életbiztositiais } \\
\text { (nem-élet járadék tartalék } \\
\text { és UL nélkul) }\end{array}$ & Unit-linked \\
\hline Kockázati ráhagyás ${ }^{6}$ & $2,2 \%$ & $2,4 \%$ & $2,1 \%$ \\
\hline
\end{tabular}

4. táblázat: Kockázati ráhagyás

\subsubsection{Nem-életbiztosítási tartalékok}

Az új rezsimre történő átállás talán a legmarkánsabban a nem-életbiztosítási tartalékoknál érezteti hatását. A Szolvencia II szerinti érték (ide sorolva azon betegségbiztosításokra és nem-életbiztosítási járadékokra képzett tartalékokat is, amelyeket az élet ágban kell kimutatni) a Szolvencia I-es érték ${ }^{7} 62$ százaléka. A csökkenésben a legfontosabb szerepet az játssza, hogy a Szolvencia I-es tartalékok esetében a jövőbeni pénzáramokat nem szabad diszkontálni. A 2014-es hatástanulmány nem-életbiztosítási pénzáramait alapul véve ${ }^{8}$ a 
diszkontálás 21,5 százalékkal csökkenti a tartalék értékét, ami jelentősen elmarad a 2014es hatástanulmányban tapasztalt csaknem 27 százalékos mértéktől. Az eltelt egy év alatt az alkalmazandó kockázatmentes forint hozamgörbe jelentősen, a fenti CF-kkal súlyozott átlag alapján 157 bázisponttal süllyedt. Ez a hozamesés a Szolvencia II-es nem-életbiztosítási tartalékok (a 2014-es hatástanulmány pénzáramait alapul véve) csaknem 9 százalékos növekedését eredményezte. A diszkonthatást tompítja, hogy a Szolvencia I-es tartalékok többségénél a jövőbeni infláció sem játszik szerepet, illetve a felelősségbiztosítási járadékok növekedésének kompenzációjára is csak az alacsony (a jogszabályok alapján maximum 0\%os, a gyakorlatban sokszor negatív) technikai kamatláb alkalmazása szolgál’

Másfelől a Szolvencia I-es tartalékokat prudensen kell megképezni. A Szolvencia II-es rezsimben a legjobb becslésen felül a tőketartás költségét ellentételező kockázati pótlékot is kell képezni (melynek legjobb becsléshez viszonyított mértéke 2014-ben a nem-életbiztosítások esetében $10 \%$ lett), a prudencia szerepét a tartalékolási kockázatokat is lefedő szavatoló tőke veszi át. Az új rezsimre történő áttérés miatti tartalékcsökkenés hatása rendkívül heterogén az egyes biztosítók esetében, illetve egy esetben növekedést tapasztalhatunk.

\section{$\mathrm{Az}$ új rezsimre történő áttérés miatti \\ tartalékcsökkenés hatása heterogén.}

Ebben nagy szerepet játszik a Szolvencia II-es díjtartalékban megjelenő jövőbeni nyereség. Az új rezsimben a nem-életbiztosítási tartalékok legjobb becslését két részre kell bontani: díjtartalékra és kártartalékra. Ezek összegéhez adódik a kockázati ráhagyás. A kártartalék a már bekövetkezett, míg a díjtartalék a jövőbeni károkra nyújt fedezetet. Mindkét tartalékrészt csökkentik a jövőben fizetendő díjak: a kártartalék esetén a vonatkozási időpontig, a díjtartalék esetén a vonatkozási időponttól a szerződések határáig terjedő kockázatokra eső díjrészek. A díjtartalék (jó közelítéssel) két részre bontható: a meg nem szolgált díjak tartalékára, illetve a vonatkozási időponttól a szerződések határáig tartó időszakra eső (jövőbeni) díjak várható nyereségtartalmára. Ez az előrehozott nyereség (mint negatív tartalékrész) a diszkonthatás mellett a másik legjelentősebb tényező, ami az új rezsimre történő áttérés miatti tartalékcsökkenésért felelős, és amit a Szolvencia I-es meg nem szolgált díjak tartaléka és a Szolvencia II-es díjtartalék különbségével lehet becsülni. Az így adódott előrehozott nyereség a Szolvencia I-es tartalék 7,9 százalékával egyezik meg, azaz megközelítőleg ennyivel járul hozzá a tartalék csökkenéséhez.

A jövőbeni díjak várható nyereségtartalma az egyes biztosítóknál is alapvető szerepet játszik a tartalékcsökkenésben. Kiválasztva azt a nyolc biztosítót, ahol a legjelentősebb az értékelési különbözet (amelyeknél legalább 45\%-os a csökkenés mértéke), illetve azt a nyolcat, amelyek esetében a fenti módon becsült elörehozott nyereség a legjelentősebb a Szolvencia I-es tartalékhoz viszonyítva (legalább 10\%), a két listának hat közös eleme van. Azaz a legtöbb elörehozott nyereséggel számoló biztosítók közül kerülnek ki a legnagyobb tartalékcsökkenést mutató biztosítók, és viszont.

A nem-életbiztosítási tartalékok viszontbiztosításra jutó része még a bruttó tartalékoknál is jelentősebb mértékben, összességében 54 százalékkal csökken az új rezsimre való áttéréssel. A viszontbiztosítóra jutó rész csökkenésének mértéke is rendkívül szóródik az egyes biztosítók között. A bruttó tartalékok és a viszontbiztosítóra jutó részek esetén tapasztalható csökkenési mértékek között jelentős eltérések is elöfordulnak, de a 0,74-es korreláció szoros kapcsolatot jelez.

\subsection{Az eszközök kötelezettség feletti többlete és a szavatoló tőke alakulása}

A korábbiakban bemutatott, Szolvencia II szerint értékelt eszközök és kötelezettségek különbségeként áll elő az ún. „eszközök kötelezettségek feletti többlete” tétel, amely a szavatoló tőke alapját képezi. Az eszköztöbblet nem egyezik meg a szavatoló tőkével, hanem ki kell igazítani levonandó, illetve hozzáadandó tételekkel aszerint, hogy a biztosítónál mely szavatolótőke-elemek képesek a jövőbeli veszteségeket elnyelni. A korrekciót követően határozható meg a végleges, figyelembe vehető szavatoló tőke értéke, amelyet azok minősége (főleg tartós rendelkezésre állásuk és alárendeltségük) alapján egy háromfokozatú, ún. „Tier” rendszerbe kell besorolni.

A hatástanulmányban néhány biztosító jelentett második, sőt, harmadik szintű szavatolótőke-elemet is. Utóbbiak mennyiségüket tekintve azonban nem jelentősek, így szektorszinten a szavatoló tőke továbbra is szinte teljes mértékben (99,2\%) a legjobb minőségü, Tier 1-esben áll.

\begin{tabular}{|l|c|c|c|}
\hline & Szolvencia I 2014 & QIS2014 & $\begin{array}{c}\text { QIS2014/ } \\
\text { Szolvencla I 2014 }\end{array}$ \\
\hline Eszközök kötelezettségeket meghaladó több- & 233782 & 501945 & $215 \%$ \\
lete & 190673 & 480949 & $252 \%$ \\
Szavatoló tốke & 77788 & 259159 & $333 \%$ \\
ebböl: tốkeszükséglet feletti többlet & 112884 & 221791 & $196 \%$ \\
\hline Tókeszūkséglet & & &
\end{tabular}

5. táblázat: A szavatoló tőke levezetése a 2014. évi hatástanulmány, valamint a Szolvencia I mérleg alapján

A szavatoló tőke elemei közül a jegyzett tőke és a tőketartalék - a Szolvencia I-hez hasonlóan - számottevő arányt képvisel a Szolvencia II rezsimben is. Új elemként jelenik meg viszont az átértékelési különbözet (más néven rekonsziliációs tartalék), amely az eszközök és kötelezettségek Szolvencia II szerinti átértékelése után fennmaradó eszköztöbblet csökkentve a számviteli jegyzett tőkével és tőketartalékkal, valamint olyan tételekkel, amelyek természetüknél fogva nem vonhatók be az esetleges veszteségek fedezésére. Az átértékelési különbözet 
biztosítja, hogy az eszközök kötelezettségek feletti többlete azonos legyen az alapvető szavatoló tőke összegével, biztosítva ezzel a Szolvencia II mérleg eszköz- és kötelezettségoldalának összhangját. A QIS2014 hatástanulmányban a szavatoló tőke Szolvencia I szerinti értékéhez viszonyított növekedésének kétharmada tulajdonítható az átértékelési különbözetnek.

\subsection{Szavatolótöke-szükséglet}

A biztosítási szektor szavatolótőke-szükséglete 97 százalékos emelkedést mutat a Szolvencia I-hez képest. A Szolvencia II rendszerben ugyanis számos olyan kockázatra kell a biztosítóknak jelentős nagyságú tőkét képezniük, amelyek explicit módon nem jelennek meg a jelenlegi szabályok szerinti szavatolótőke-szükséglet számításban, illetve a jelenlegi tőkeszükséglet-számítás bemenő adataival (pl. tartalékállomány, díjbevétel, viszontbiztosítási arány) nem állnak arányos megfeleltetésben. Ilyen kockázatnak minősül tipikusan a partner-, a piaci vagy a müködési kockázat.

A biztosítási szektor Szolvencia II szerinti szavatolótőke-szükséglete 219 milliárd forint volt 2014. év végén, melynek meghatározó részét három kockázati modul adta: az élet- és nem-életbiztosítási, valamint a piaci kockázatok.

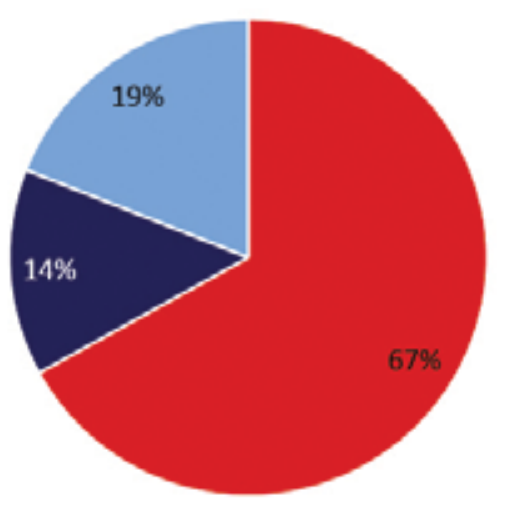

- Átértékelési különbözet

- Jegyzett töke = Töketartalék

3. ábra: A szavatoló tőke összetétele

\subsubsection{Piaci kockázat}

A teljes diverzifikálatlan szavatolótőke-szükséglet 27 százalékát adó piaci kockázati modulban a biztosítók a különböző pénzügyi változók mozgásából eredő kockázati kitettségüket számszerűsítik. A QIS2014-ben a legjelentősebb részmodul a részvénykockázat és a koncentrációs kockázat volt, ami a diverzifikálatlan piaci kockázati modul szavatolótőke-szükségletének 28, illetve 27 százalékát adja, összesen csaknem 80 milliárd forint értékben.

\section{Kamatlábkockázat}

A hazai biztosítók kamatláb-kockázati kitettsége a harmadik legjelentősebb az egyes részmodulok között, a nem diverzifikált piaci kockázati tőkeszükségletnek 15 százalékát teszi ki. Ez lényegesen kisebb, mint a QIS2013 során tapasztalt érték, ahol a piaci kockázat mintegy negyede származott a kamatlábkockázatból. A visszaesés döntő részben a hozamok 2014-ben is folytatódó csökkenésének köszönhető. Nem történt változás azonban abban, hogy a hazai intézmények többségének (a 29 résztvevő biztosítóból 22-nek) továbbra is a hozamemelkedés jelenti a nagyobb kockázatot. A sokk irányát és mértékét az eszközök és kötelezettségek kamatérzékenysége határozza meg alapvetően, amely nagymértékben függ az eszközök és kötelezettségek áltagos hátralévő futamidejétől (duration). A két oldal duration-jének „egyeztetése” az ALM feladata a biztosítón belül, amelynek sikeressége esetében a kamatlábkockázatra számított tőkekövetelmény minimálisra csökkenhet.

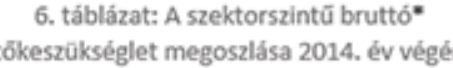

\begin{tabular}{l|c|}
\hline \multicolumn{1}{|c|}{ QIS2014 } \\
\hline Piaci kockázat & 94968 \\
Partnerkockázat & 37427 \\
Életbiztositási kockázat & 78178 \\
Egészségbiztositási kockázat & 11138 \\
Nem-életbiżtosítási kocká- & 111528 \\
zat & \\
Immaterílis javak kocká- & 257 \\
zata & 25487 \\
\hline Müködési kockázat & -96951 \\
\hline Diverzifikáció & -42731 \\
\hline Korrekciók & $\mathbf{2 1 9 3 0 0}$
\end{tabular}

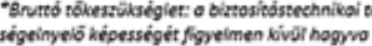

millió
4. ábra: A szektorszintũ bruttó tōkeszükséglet megoszlása 2014. év végén

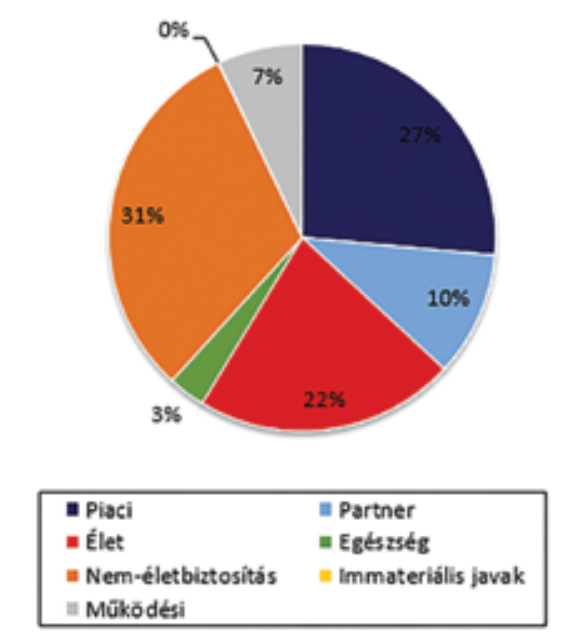

Kamatrés (spread) kockázat

A kamatrés sokk mértékét alapvetően az instrumentum hitelkockázati minősítése (rating), valamint annak átlagos hátralévő futamideje (duration) adja. A kamatrések megváltozása elsősorban a vállalati kötvények értékét befolyásolja. A QIS2014-ben a nem diverzifikált piaci kockázati tőkeszükséglet 10 százalékát teszi ez a részmodul, amely érték - az összetétel-hatás kiszűrése után - negyedével haladja meg a QIS2013- 
ban tapasztaltat. A növekedés legföképpen a look through elv alkalmazásának, kisebb részben a növekvő vállalatikötvény-állománynak tulajdonítható.

\section{Részvénykockázat}

A részvénykockázat a teljes, diverzifikáció előtti piaci kockázati tőkeszükséglet 28 százalékát adja, abszolút értékben pedig meghaladja a 40 milliárd Ft-ot. A viszonylag magas érték ellenére a kockázat megoszlása igen egyenlőtlen a piaci szereplők között: a részvénykockázati tőkeszükséglet 43 százaléka két biztosítóhoz köthető, míg több intézmény esetében (a kitettséggel összhangban) elhanyagolható a kockázat. A tőkeszükséglet 61 százaléka 2-es típusú részvényekhez kötődik, amelyekkel nem OECD vagy EAA tagországok tőzsdéin kereskednek, valamint tőzsdén kívüli részvények, árutőzsdei termékek és egyéb, alternatív befektetések tartoznak ebbe a kategóriába.

\section{Ingatlankockázat}

A diverzifikáció előtti piaci kockázati tőkeszükséglet mindössze 5 százalékát adja eza részmodul, annak ellenére, hogy az előző hatástanulmányhoz képest jelentősen megnőtt az értéke. Az emelkedést a fent is említett look-through elv alkalmazása okozta.

Koncentrációs kockázat

A részvénykockázattól alig elmaradó piaci koncentrációs kockázat azon veszteség értékét mutatja, amely az adott kibocsátó nemfizetése (csődje) esetében a felé fennálló eszközök azonnali értékcsökkenéséből származik. A hazai intézményeknél a kockázat

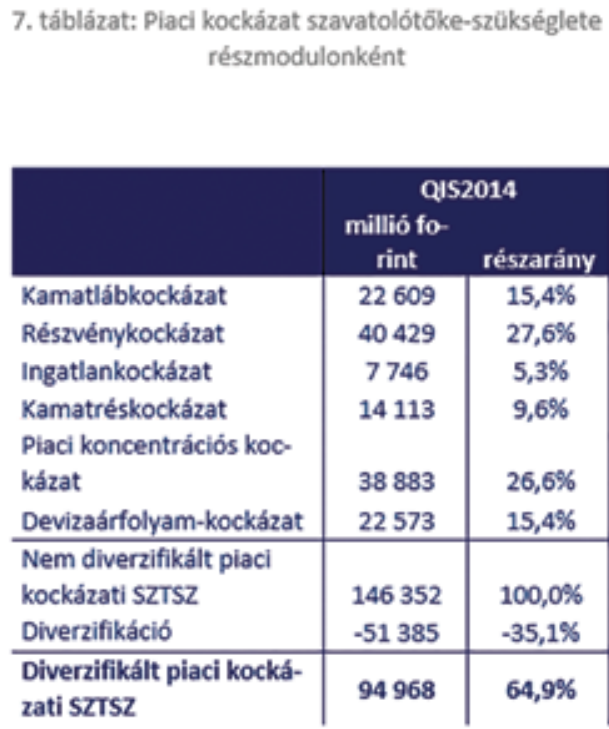

$$
\text { 5. ábra: A piaci kockázati modul szavatolótōke- }
$$
szükségletének megoszlása

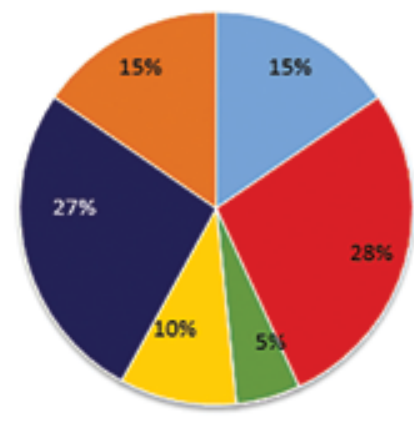

\section{Kamatlibbockázat}

- Reszivenykockazat

- Ingatiankockazat

- Piaci konsentrációs kockázat

nevizaárfolyam-kockazat jellemzően vállalati kötvények, csoporthoz tartozó vagy kiemelt stratégiai partnerek által kibocsátott értékpapírok tartásából fakad. Ugyanakkor a kellően diverzifikált portfóliók esetében nem lép fel koncentrációs kockázat. Ez magyarázza, hogy a hazai biztosítók mintegy felénél a részmodul tőkeszükséglete nulla.

\section{Devizaárfolyam-kockázat}

A devizaárfolyam kockázati almodul tőkeszükséglete egy külföldi devizában denominált eszköz tartásából eredő azon kockázatot számszerüsíti, amely a hazai deviza külföldi devizával szembeni 25 százalékos azonnali le- vagy felértékeléséből adódik. E stressz a biztosító eszköz- és forrásoldalát is érintheti. A QIS2014-ben a részmodul tőkeszükséglete a nem diverzifikált piaci kockázati tőkeszükséglet 16 százalékát teszi ki, mely érték - azonos biztosítói bázison összehasonlítva - a QIS2013-hoz képest közel megduplázódott. Ezen robusztus növekedés intézményspecifikus okokra vezethető vissza, tipikusan az euróalapú biztosítások értékesítésének felfutására.

\subsubsection{Partner-nemteljesítési kockázat}

A hazai biztosítók partnerkockázata 2014 végén 37,4 milliárd forint volt, ami a teljes diverzifikálatlan szavatolótőke-szükséglet 10 százalékának felel meg. A partnerkockázat szempontjából kétféle kitettség különböztethető meg: ún. 1. típusú (kisszámú és nehezen diverzifikálható partnerek, nagy egyedi kitettség) és 2. típusú (nagyszámú, jól diverzifikálható partnerek, kis egyedi kitettség). A hazai intézmények többségénél az 1. típusú kitettség a meghatározó.

A biztosítók legjellemzőbb 1. típusú partnerei a viszontbiztosítók és a számlavezető hitelintézetek, míg a 2. típusú kitettség leginkább a közvetítési tevékenységhez köthető. A nagy nemzetközi csoportokhoz tartozó biztosítók esetében a csoporttagokkal szembeni követelések is jelentős szerepet játszanak. A művelt ágak alapján a kompozit biztosítók esetében legnagyobb arányú az 1. típusú kitettség, ugyanakkor az 1. és a 2. típusú kitettség közötti diverzifikációs hatás is itt a legjelentősebb. A két kitettség megoszlása változott 2013 vége óta: a bankbetétek növekedése az 1. típusú kitettség emelkedését (83\%-ról 87\%-ra) vonta maga után. Ennek egyik oka, hogy az intézmények egy része a kéthetes MNB kötvényeket használta a likviditásszükséglet kezelésére, mely lehetőség azonban 2014 augusztusában megszűnt, a felszabaduló pénzösszegek pedig a bankbetéteket gyarapították.

\subsection{3 Életbiztosítási kockázat}

A 78 milliárd forintra rúgó életbiztosítási kockázatra számolt tőkekövetelmény a teljes diverzifikálatlan tőkekövetelmény 22 százalékát adja. A részmodulok közül 
a törlési kockázat a legjelentősebb, ez adja az életbiztosítási kockázatok több mint felét. A törlési kockázaton belül öt-öt esetben a törlési arányok felfelé, illetve lefelé történő sokkolt értéke, míg kilenc biztosítónál a tömeges törlés feltételezés esete határozza meg a tőkeszükségletet. A törlési kockázat után a költségkockázat a második legjelentősebb részmodul (26,3 milliárd forint), míg a harmadik legjelentősebb részmodul, a halandósági kockázat ennek már csak mintegy harmadát teszi ki.

A részmodulok piaci átlagtól lényegesen eltérő megoszlása egyedi intézményi okokra vezethető vissza. A hosszú élet kockázat jellemzően a kötelező gépjármü-felelősségbiztosítás (továbbiakban: kgfb) járadékos állománnyal rendelkező nem-életbiztosítóknál jelentős. A csoportos életbiztosításokkal rendelkező biztosítók esetében a piaci átlagot jóval meghaladja a katasztrófakockázat aránya, míg néhány kis piaci részesedésű intézménynél a költségkockázat a kiemelkedő.

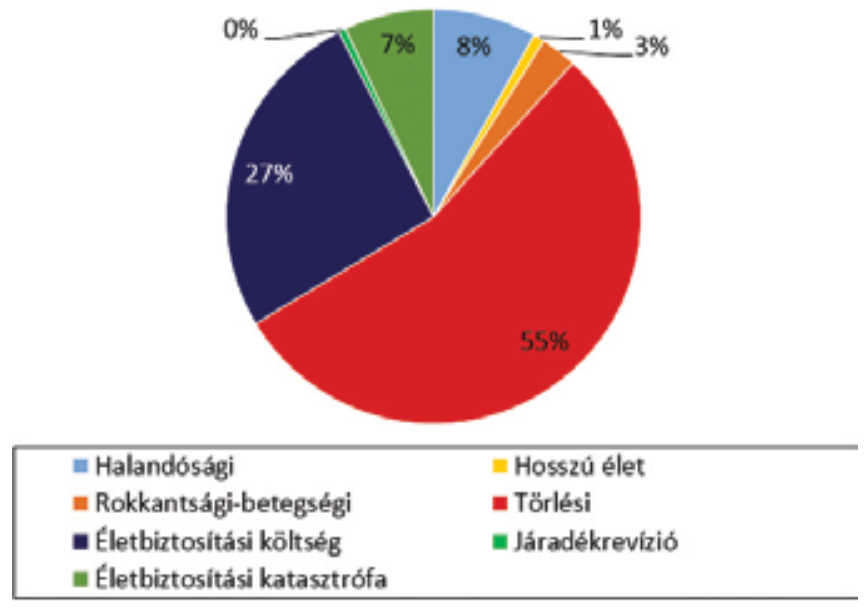

6. ábra: Életbiztositási kockázat megoszlása

\subsubsection{Nem-életbiztosítási kockázat}

A szavatolótőke-szükségleten belül a nem-életbiztositási kockázat a legjelentösebb modul, a teljes, nem diverzifikált tőkeszükséglet 31 százalékát teszi ki. A modulban megképzett tőkeszükséglet 65 százalékát a dij- és tartalékkockázat adja, a katasztrófakockázat részaránya 33 százalék, míg a nem-életbiztositási törlési kockázat továbbra is elenyésző hányadát képezi a hazai intézmények nem-életbiztositási tőkeszükségletének. Az átlagos megoszlás azonban nem tekinthető tipikusnak, az arányok intézményi szinten jelentősen szóródnak.

Dij-és tartalékkockázat, illetve törlési kockázat

2014 végén a dí- és tartalékkockázat (87 milliárd forint) üzletágankénti (LoB) megoszlásánál az üzletágak jelentőségével megegyező nagyságú kockázatokat találunk. A legnagyobb kockázat ebben a részmodulban a gépjármü-felelősség (39\%), a tủz- és egyéb vagyoni károk (34\%), majd az egyéb gépjármű (14\%) szegmenshez kötődik. Az alábbi ábrán az elhanyagolható, 1 százalék körüli súllyal bíró LoB-okat nem ábrázoltuk.

Nem-életbiztositási katasztrófakockázat

A katasztrófakockázati részmodulon belül legjelentősebb a természeti katasztrófakockázat tőkeszükséglete, amely a teljes katasztrófakockázat tőkeszükségletének 69 százalékát teszi ki. A katasztrófakockázatot számító biztositók három biztosító kivételével csak Magyarország régióra jelentettek kitettséget, ugyanakkor a Magyarországon belüli CRESTA zónákra vonatkozó adatokat ezúttal nem szolgáltattak a biztosítók

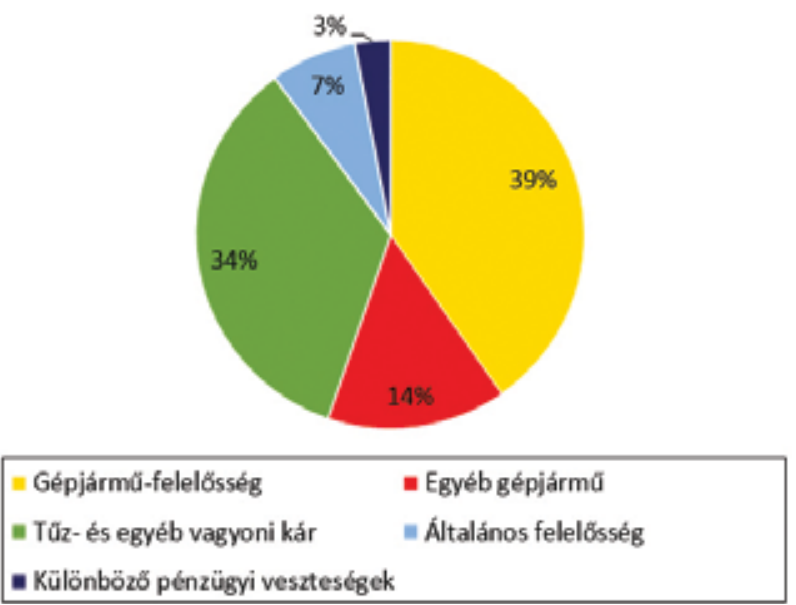

7. ábra: Dij-és tartalékkockázat üzletágankénti megoszlása

A természeti katasztrófakockázat részmoduljai közül Magyarországon a földrengés-kockázati, valamint az árvízkockázati részmodulok tőkeszükségletét kell kiszámolni, ugyanakkor több biztosító is jelezte az előző hatástanulmányok során, hogy számításaik szerint a szélviharkockázat sem elhanyagolható. A beküldött adatok alapján a természeti katasztrófakockázat háromnegyedét azárvízkockázati részmodul teszi ki, a maradék 25 százalék a földrengéskockázat.

Az ember okozta katasztrófakockázat tőkeszükségletének legjelentősebb részét, 45 százalékát a tủzkockázati részmodul adja. Ezen kívül meghatározó még azáltalános felelösségi, valaminta gépjármü-felelösségi kockázatokra vonatkozó részmodulok tőkeszükséglete, amelyek az ember okozta katasztrófakockázat tőkeszükségletének 24, illetve 20 százalékát teszik ki.

\subsubsection{Egészségbiztositási kockázatok}

A 11,1 milliárd forintot kitevő egészségbiztositási kockázatra számolt tőkekövetelmény a teljes diverzifikálatlan tőkekövetelmény 3 százalékát adja. A kockázatot a nem-életbiztositási (40\%) és az életbiztosítási tartalékolási technikákhoz hasonlóan (18\%) kezelt egészségbiztosí- 
tási dijkockázat és az egészségbiztosítási katasztrófakockázat (42\%) alkotja. A kockázat koncentrált, döntően néhány intézményhez köthető. Az egészségbiztosítási kockázatra számolt tőkekövetelmény súlya a tavalyi hatástanulmányhoz képest növekedett, ennek elsődleges oka módszertani változás: a hazai biztosítók korábban - immaterialitási okokra hivatkozva - nem számítottak tőkeszükségletet e kockázatokra.

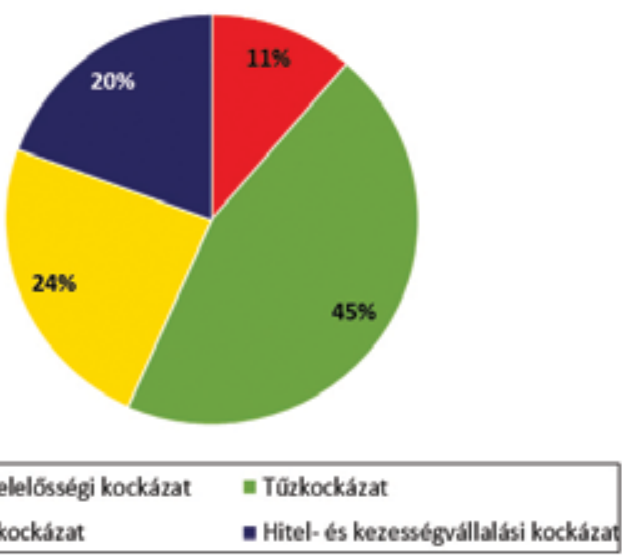

8. ábra: Ember okozta katasztrófakockázat

\subsubsection{Müködési kockázat}

A működési kockázat tőkeszükséglete a teljes nem diverzifikált szavatoló-tőkeszükséglet 7,1 százalékát képezi. A működési kockázatra számolt tőkeszükséglet díjarányos vagy tartalékarányos és unit-linked típusú részből tevődik össze. Az élet, nem-élet és kompozit biztosítóknál egyaránt a díjbevételre képzett működési kockázati szavatolótőke-szükséglet a legjelentősebb.

\subsection{A biztosítástechnikai tartalékok és halasztott adók veszteségelnyelő hatása}

A standard formula alapján számolt szavatolótőke-szükséglet az alapvető szavatolótőke-szükséglet és a működési kockázatra meghatározott tőkeszükséglet összege, amihez hozzá kell adni a biztosítástechnikai tartalékok és a halasztott adók veszteségelnyelő képessége miatti (negatív előjelü) korrekciót (azaz a biztosítástechnikai tartalékok, illetve a halasztott adók veszteségelnyelő hatását).

A biztositástechnikai tartalékok veszteségelnyelő hatása

A Szolvencia II-es szabályozás értelmében a tartalékok a veszteséget azáltal nyelik el, hogy ezek a sokkok nemcsak az eszközoldalra, hanem a kötelezettségekre, és így a tartalékokra is hatnak. A hozamkörnyezet csökkenésével párhuzamosan évek óta mérséklődik a várható többlethozam mértéke, így a tartalékok veszteségelnyelő képességének hatása is: 2014 végén a szavatolótőke-szükséglet mindössze 2 százalékát tette ki.

\section{A halasztott adók veszteségelnyelö hatása}

A halasztott adók miatti korrekció a tartalékok veszteségelnyelő képességéhez hasonlóan működik. A bruttó tőkeszükséglet számításánál figyelmen kívül kell hagyni, hogy a sokkszcenárió miatti veszteség kisebb adófizetési kötelezettséget is eredményez, ami csökkenti a veszteséget. Az eredmények összhangban vannak a 2014-es hatástanulmányban jelentett értékekkel, illetve a kétkulcsos társasági adó rendszerével. A korrekció a nyereséges, nagy biztosítóknál a halasztott adók veszteségelnyelő hatása nélküli szavatolótőke-szükséglet 19 százalékával (vagy azt közelítö összeggel) egyezik meg, a kicsiknél 10 százalék (vagy a körüli) az érték. A még nem nyereséges biztosítók (illetve az adót nem fizető egyesületek) esetében találkozhatunk 10 százalék alatti, illetve 0 mértékủ korrekcióval.

\subsection{Minimális tőkeszüikséglet}

A biztosítók Szolvencia II szerinti minimális tőkeszükségletének (minimum capital requirement, továbbiakban: MCR) számítása három lépésből áll:

1. a biztosító először meghatározza a lineáris formulával - díjelőírások, tartalékok, kockáztatnak kitett összegek alapján - számított minimális tőkeszükségletét (ún. MCRlinear);

2. a második lépésben a lineáris formulával számított minimális tőkeszükséglet értékét felülírhatja az MCR alsó korlát (MCRfloor, a szavatolótőke-szükséglet 25\%-a) és az MCR felső korlát (MCRcap, a szavatolótőke-szükséglet 45\%-a) értéke;

3. az így kapott értéket - amely már a 25-45 százalékos sávba esik - a harmadik lépésben ismét módosíthatja az úgynevezett abszolút alsó korlát, amelynél semmi esetre sem lehet alacsonyabb a biztosító minimális tőkeszükséglete.

A minimális tőkeszükséglet abszolút alsó korlátja életbiztosító esetén 3,7 millió euró, nem-életbiztosító esetén 2,5 millió euró vagy 3,7 millió euró attól függően, hogy rendelkezik-e engedéllyel bizonyos ágazatok művelésére, kompozit biztosító esetén pedig a megfelelő összegek együttesen adják a minimális tőkeszükséglet abszolút alsó korlátját.

A QIS2014-ben részt vevő 29 biztosító közül 5 esetén a lineáris formulával számított minimális tőkeszükséglet a 25-45 százalékos sávba esett, két esetben az MCR alsó korlát, három esetben az MCR felső korlát, és 19 biztosító esetén az abszolút alsó korlát határozta meg a minimális tőkeszükségletet. Fontos megjegyezni, hogy az abszolút alsó korlát Szolvencia I-es megfelelője a minimális biztonsági tőke, amely a 2014 végi Szolvencia I szerinti adatszolgáltatás alapján a 29 résztvevő közül 15 biztosító esetében határozza meg a tőkeszükségletet. A biztosítók minimális tőkeszükséglete a szavatolótőke-szükségletük 38 százaléka, amely érték megközelíti az elméleti kalibrációt (SCR 35\%-a). 
Nyolc biztosító esetében fordult elő, hogy a végleges - vagyis a korlátok figyelembevételével meghatározott - minimális tőkeszükséglet meghaladta a standard formulával számított szavatolótőke-szükséglet értékét, ezért a minimális tőkeszükséglet határozta meg e biztositók tőkeszükségletét. Mind a nyolc biztosító a kisebb biztosítók közé tartozik, melyek kisállománynyal rendelkeznek, vagy speciális biztosításokat kínálnak, és minimális tőkeszükségletüket az abszolút alsó korlát adja.

\subsection{A hazai biztosítási szektor tőkefeltöltöttségének alakulása Szolvencia II alapon}

\subsubsection{Szektorszintű és intézményi tőkefeltöltöttség}

A szektor 2014 végi tőkefeltöltöttsége 217 százalék Szolvencia II, és 169 százalék Szolvencia I alapon. A tőkemegfelelési mutató emelkedését az okozza, hogy bár mind a szavatolótőke-szükséglet, mind a szavatoló tőke nagysága megkétszereződik, utóbbi mennyiségi hatása erősebb. Ez a tőketöbblet jelentős emelkedését okozza (78 milliárd forintról 260 milliárd forintra).

A 2013 végi 223 százalékos feltöltöttséghez képest a mindkét hatástanulmányban szereplő 23 biztosító tőkemegfelelése összességében mérséklödött, 2014-ben már csak 217 százalék volt. A csökkenést az átértékelési különbözet csökkenése mellett az is magyarázza, hogy a QIS2013 még az első negyedév során készült, az adatszolgáltatás így még nem minden esetben mutatta a kifizetni szánt osztalékok hatását. Becsléseink alapján ez önmagában 2,5 százalékponttal növelte a 2013 végi feltöltöttséget.

A szektor 2014 végi tőkefeltöltöttsége 217 százalék

Szolvencia II, és 169 százalék Szolvencia I alapon.

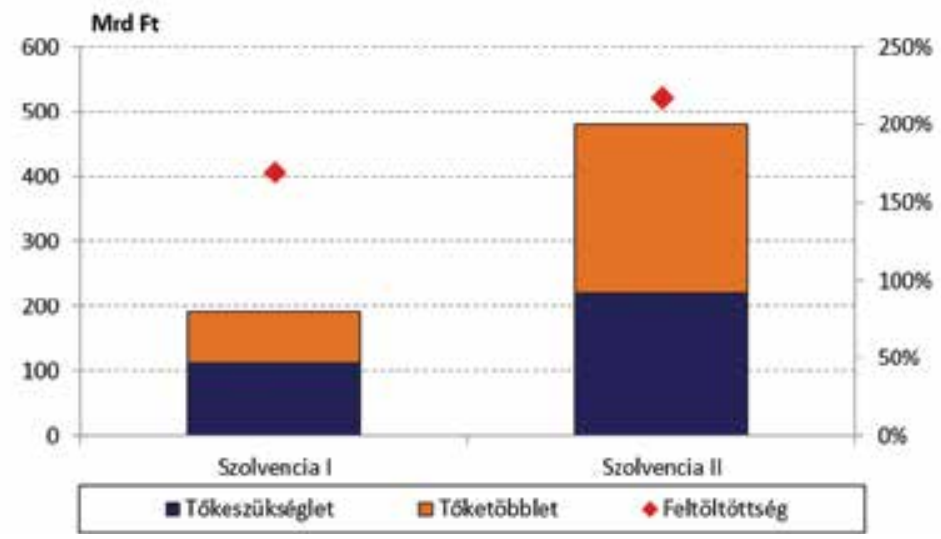

9. ábra: A hazai biztosítási szektor feltöltöttsége Szolvencia II alapon

Szektorszinten tehát kielégítőnek nevezhető a feltöltöttség, intézményi szinten azonban jelentős eltéréseket látni. 2013 év végén két intézmény feltöltöttsége nem érte el a 100 százalékot
Szolvencia II alapon, a QIS2014-es hatástanulmányban ez a szám négyre nőtt.

Két biztosító az MCR, a másik kettő pedig az SCR szerint nem felel meg a jogszabályi elvárásoknak. A résztvevők közül további két biztosító feltöltöttsége található a 120 százalékos

\section{Szektorszinten kielégítő a feltöltöttség, intézményi}

szinten jelentős eltéréseket látni.

szint alatt vagy közelében. A Szolvencia I-es szabályozás alapján csupán két intézmény nem érte el a törvényileg elöírt 100 százalékot, míg három biztosító esetében a mutató a 100-120 százalék közötti sávban mozog

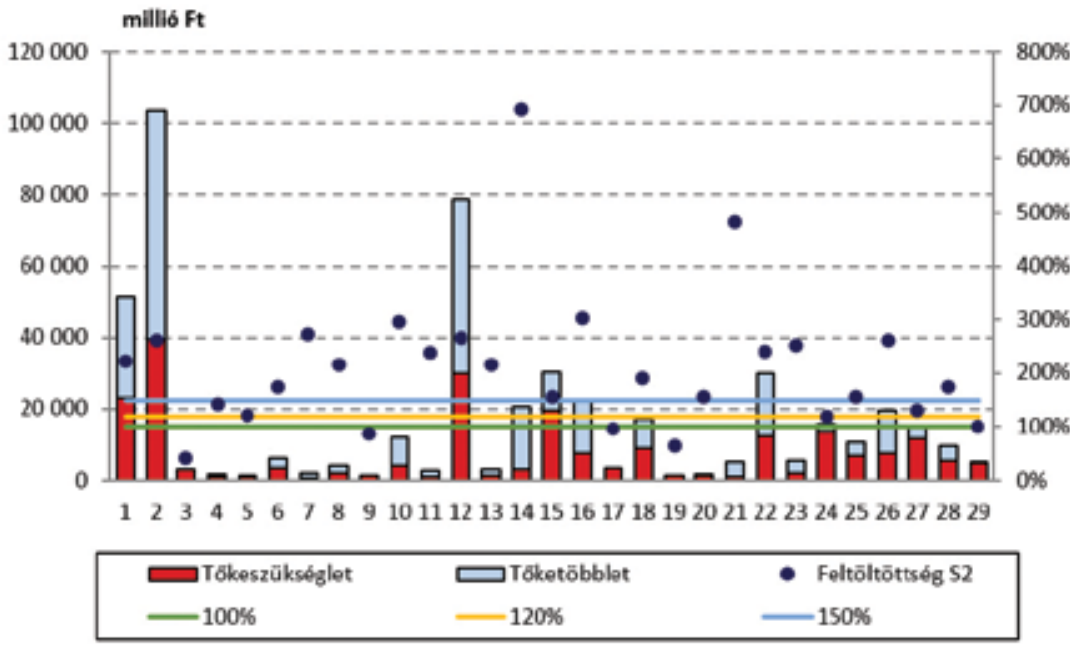

10. ábra: A hazai biztositási szektor feltöltöttsége Szolvencia I és Szolvencia II alapon 2014 végére vonatkozóan

\subsubsection{A tőkefeltöltöttség alakulása 2009-2014 között}

A 2009 végére vonatkozó hatástanulmánytól kezdve összevetettük a korábbi hatástanulmányok eredményeit. Mivel az egyes felmérések piaci lefedettsége eltérő, kizárólag a mind az öt hatástanulmányban részt vevő 12 intézmény adatait aggregáltuk, elkerülve az eltérő összetételből fakadó torzításokat. A 12 biztosító piaci részesedése az egyes években 70 százalék körül ingadozik.

Látható, hogy bár a Szolvencia I szerinti tőkemegfelelési mutató is változott az évek során, ám a Szolvencia II szerinti feltöltöttség ingadozása meghaladja ezt a szintet. Mivel a Szolvencia I szerinti tőkehelyzetet befolyásoló folyamatok döntően megjelennek a Szolvencia II-ben is, a két rezsim közötti eltérésért a módszertani változásokon túl nagyrészt a piaciárak változása a felelős. 
A piaci árak ingadozása miatt a Szolvencia II rendszerben a tőkehelyzet a jelenleginél várhatóan volatilisebben fog alakulni. A megnövekvő volatilitást jól szemlélteti a 2011 és 2013 végi adatok közötti eltérés: két év alatt - a hozamkörnyezet jelentős változása mellett (12. ábra) - a Szolvencia I szerinti feltöltöttség kevesebb mint 1 százalékkal emelkedett, míg a Szolvencia II szerinti mutató jóval nagyobb mértékben, 14 százalékkal növekedett.

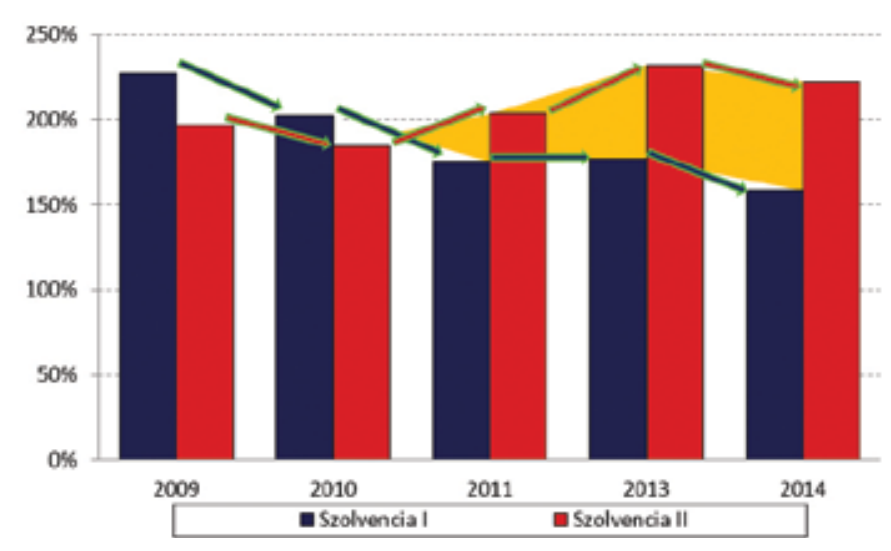

11. ábra A tökefeltöltöttség alakulása 2009 és 2014 között

\subsection{Adatminőség}

A QIS2014 hatástanulmány során nem álltak rendelkezésre beképletezett adatszolgáltatási táblák, azonban az úgynevezett Tool for Undertakings (TfU) eszköz hibaüzenetet generált azon esetekben, amikor az ellenőrző képletek az adatok közt inkonzisztenciát azonosítottak. Az MNB a beérkezett adatokon további plauzibilitás-vizsgálatot hajtott végre, amelynek alapján jelentős számban, a hatástanulmányban részt vevő összes biztosító esetén szükség volt hibajavításra vagy kérdések megválaszolására. Megjegyezzük, hogy - vélhetően a képletek hiánya, valamint több esetben a csoportszintü kitöltés miatt - azon biztosítók esetében is fordultak elő jelentős hibák, amelyek rendszeresen részt vesznek a Szolvencia II hatástanulmányokban.

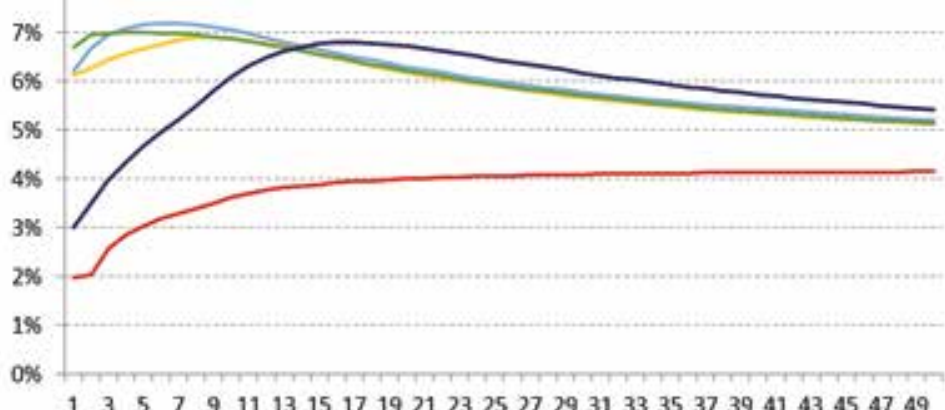

12. ábra: A forint kockázatmentes hozamgörbe év végi értékei

\section{LÁBJEGYZETEK}

'A 2. ábrán szereplő mérlegek eszköz- és forrásoldala a korrekciós tételek figyelembevétele miatt nem egyezik meg.'. Pareto-optimalitas alatt a kozgazdasagtan azz erti, hogy nem lehet senkinek a helyzeten javitani anelkul, hogy valaki masé romolna. kockazatmentes hozamgorbèvel valo diszkontalass, a jovobeli nyereségek biztositastechnikai tartalekban torteñó elismerése és egyes Szolvencia I szerinti tartalekfajatak (nagy károk tar aleka, káringadozasi tartalek) Szolvencia II szerinti megszün kivul hagyva a nem-életbiztositási járadéktartalékokat (hagyományos és UL biztositásra egyaránt).

5 A Szolvencia II-es érték a legiobb becslés és a kockázati ráhagyás, illetve az egy összegben meghatározott tartalékok összege, figyelmen kívül hagyva a nem-életbiztositási járadéktartalékokat (hagyományos és UL biztositásra egyaránt).

em tartalmazza az, ,as a whole" módszerrel becsült unit-linked tartalekot, valamint az, ,egyéb életbiztositási” tartalék a hagyományos eletiz tostús, egessségbiźn megadott értékektöl. Az eltérések az összpiaci adatokat is jelentösen torzitották, ezért a felügyeleti adatszolgâltatást vettük itt alapul A A 2014. év végére vonatkozó adatszolgáltatásban nem állnak rendelkezésre pénzáram adatok. 9 A 0\%-os technikai kamatláb azt jelenti, hogy a járadéknövekedéseket a tartalék hozamából kell finanszírozni. 10 Nem azonos a jövőben fizetendö dijakkal.

ikségleteta minimálistôkeszükséglet (MCR) határozza meg amely magasabba kockázati összegeként áll elö.

Szárazföldi gépjárművekkel kapcsolatos felelősség, Légi jármüvekkel kapcsolatos felelösség, Hajókkal kapcsolatos felelösség, Âltalános felelösség, Hitel, Kezesség és garancia

\section{HIVATKOZÁSOK}

EIOPA (2013): „Guidlines on Submission of Information to National Competent Authorities”, EIOPA-CP-13/010, https://eiopa.europa.eu/ publicationss/eiopa-guidelines/guidelines-on-submission-of-nformation-to-national-competent-authorities, letottve: 2015. október 20.

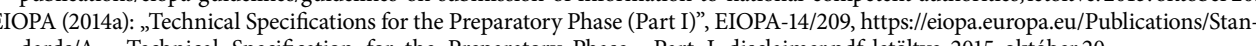
dards/A_-_Technical_Specification_for_the_Preparatory_Phase__Part_I_disclaimer.pdf, letötltve: 2015. október 20. dards/B_--Technical_Specification_for_the_Preparatory_Phase__Part_II_disclaimer.pdf, Petoltve. 2015. oltober 20. sitási üzleti tevékenység megkezdéséról lés gyakorlásáról (Szolvencia II), 52. év., L 335, 2009. december 17, http://eur-lex.europa.eu/ legal-content//HU/TXT/PDF/?uri=CELEX:02009L0138-20140523\&/rom=EN, letöltve: 2015. oktober 20 .

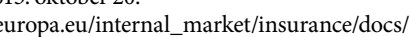
reszére, https://www.mnb.hu/letoltes/qis2013-utmutato-a-resztvevo-intezmenyek-reszere.docx, letölttve: 2015. október 20.

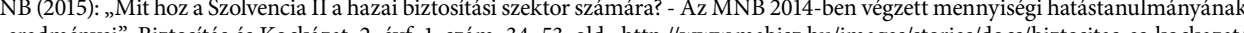
eredményei", Biztositás és Kockázat, 2. évf. 1. szám, 34-53. old., http://www.mabisz.hu/images/stories/docs/biztositas-es-kockazat/ PSZÁF (2011)

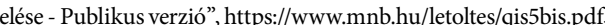
PSZÁF (2012): „A 20111 évi Szolvencia II mennyiségi hatástanulmány összefoglalója", https://www.mnb.hu/letoltes/qis2011-hatastanul-

many.pdf, letôttve: 2010. október 20.
PSZÁF (2013): „AZ EIOPA hosszú távú garanciás hatásfelmérés eredményei - Hazai eredmények és európai szintủ fejlemények", https:// www.mnb.hu/letoltes/ltga-ltga-hatasfelmeres-201308.pdf, letölttve: 2015 . október 20 .

nuity markets, Journal of Economic Dynamics and

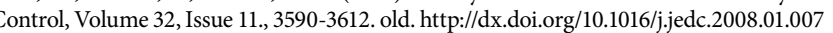

Human Mortality Database. University of California, Berkeley (USA), and Max Planck Institute for Demographic Research (Germany).

Kottikoff, L. J., Spivak, A. (1981): The Family as an Incomplete Annuities Market, The Journal of Political Economy, Vol. 89., No. 2. (Apr.,

mára az, ha az emberek tovább élnek? Szociológiai Szemle, 23(3), 51-83. old. R. (1999): New Evidence on the Money's Worth of Individual Annuities, The American Economic Review, Vol. 89, No. 5. (Dec., 1999), 1299-1318. old. http://dx.doi.org/10.3386/w6002 53. evvf október 873-879. old

Sis.êl. Aktober, 873-879. old. 